\title{
Molecular Single-Cell Analysis of Hodgkin- and Reed-Sternberg Cells Harboring Unmutated Immunoglobulin Variable Region Genes
}

\author{
Markus Müschen, Ralf Küppers, Tilmann Spieker, \\ Andreas Bräuninger, Klaus Rajewsky, and Martin-Leo Hansmann
}

Institute for Genetics (MM, RK, KR), Department of Immunology, and the Department for Internal Medicine I (MM, RK), Universität zu Köln, Köln, and the Department of Pathology (TS, AB, MLH), University of Frankfurt, Frankfurt, Germany

\begin{abstract}
SUMMARY: Hodgkin- and Reed-Sternberg (H/RS) cells in classical Hodgkin's disease of the B lineage are the clonal progeny of antigen-experienced $\mathrm{B}$ cells harboring highly mutated immunoglobulin variable (V) region genes. Based on the detection of obviously destructive somatic mutations in a fraction of cases, we speculated that $\mathrm{H} / \mathrm{RS}$ cells may be derived from a pre-apoptotic germinal center B cell. Seemingly contradicting this speculation, we present here the first case of classical Hodgkin's disease with H/RS cells harboring unmutated, potentially functional $\mathrm{V}$ region genes, which may indicate the derivation of the H/RS clone from a naive B cell. However, germinal center founder cells, which have not yet acquired somatic mutations, already have the intrinsic propensity to die by apoptosis. Thus, the rare occurrence of $\mathrm{H} / \mathrm{RS}$ cells with unmutated $\mathrm{V}$ genes is expected if the H/RS cells are derived from the pool of pre-apoptotic germinal center B cells. (Lab Invest 2001, 81:289-295).
\end{abstract}

\begin{abstract}
I n classical Hodgkin's disease (cHD), Hodgkin- and 1 Reed-Sternberg (H/RS) cells typically account for less than $1 \%$ of cells within a complex admixture of lymphocytes, plasma cells, histiocytes, and eosinophils (Burke, 1992). In most cases of cHD, H/RS cells do not express $B$ lineage markers, although in more than $90 \%$ of $\mathrm{cHD}$ cases, H/RS cells represent the outgrowth of a tumor clone derived from mature antigen-experienced B cells (Küppers and Rajewsky, 1998), and derivation of $H / R S$ cells from the T lineage is rare (Müschen et al, 2000). This conclusion is based on the amplification of clonally related immunoglobulin (lg) gene rearrangements from single micromanipulated H/RS cells in 45 of 46 analyzed cases (Bräuninger et al, 1999a; Irsch et al, 1998; Kanzler et al, 1996a, 1996b; Küppers et al, 1994; Marafioti et al, 1999, 2000; Müschen et al, 2000; Ohno et al, 1998; Vockerodt et al, 1998). In all informative B-lineage cases (41 in total), the H/RS cells harbored somatically mutated variable $(V)$ region genes, indicating their (post-) germinal center (GC) B-cell origin. In 12 of 41 cases, the originally productive $\lg \mathrm{V}$ diversity (D) joining $(J)$-gene rearrangements were rendered non-
\end{abstract}

Received August 10, 2000.

The work reported herein was supported by the Deutsche Forschungsgemeinschaft through SFB 502 and Deutsche Krebshilfe, Mildred Scheel Stiftung. Ralf Küppers is supported by a Heisenberg-Award from the Deutsche Forschungsgemeinschaft. Markus Müschen is supported by an Emmy-Noether Award from the Deutsche Forschungsgemeinschaft.

Address reprint requests to: Dr. Markus Müschen, Universität zu Köln, Institut für Genetik, LFI Gebäude E4 R705, Joseph-Stelzmann-Straße 9, 50931 Köln, Germany.E-mail: markus.mueschen@uni-koeln.de functional by the introduction of stop codons, deletions, or destructive promoter mutations generated within the GC (Jox et al, 1999; Kanzler et al, 1996a; Küppers et al, 1994; Marafioti et al, 2000; Müschen et al, 2000). H/RS cells for which B-cell receptor (BCR) function was compromised by destructive somatic mutations are derived from GC B cells as BCRdeficient $B$ cells are eliminated within the GC, and thus prevented from entering the memory compartment (Küppers and Rajewsky, 1998).

GC B cells are programmed to die unless positively selected by an antigen, thus the expression of a high-affinity BCR is critical for GC B-cell survival (Liu et al, 1989). A GC B cell within the highly competitive microenvironment of the GC can be eliminated for many reasons (Liu et al, 1997; Rajewsky, 1996). For instance, a lack of positive selection of a GC B cell can be caused by destructive somatic mutations (eg, mutations generating stop codons or frame shifts), an impairment of BCR expression (eg, by transcriptional deregulation [Marafioti et al, 2000] or destructive promoter mutations), a lack of co-stimulatory signals (eg, in case of autoreactivity), or insufficient antigen affinity (eg, by introduction of replacement mutations that reduce affinity).

Possible reasons for the lack of positive selection by antigen other than obviously destructive mutations (ie, promoter or splice site mutations and mutations generating stop codons, large deletions, duplications, and/or frameshifts) evade the technical means of analysis at the single-cell level. In approximately one third of $\mathrm{cHD}$ cases, H/RS cells harbor obviously destructive Ig gene mutations [such mutations are rare 
$(<5 \%)$ in normal GC B cells (Goossens et al, 1998; Küppers et al, 1993, 1997)]. Thus, the hypothesis that $\mathrm{H} / \mathrm{RS}$ cells may commonly represent the outgrowth of a pre-apoptotic germinal center B cell was developed (Kanzler et al, 1996b; Küppers and Rajewsky, 1998).

Here we describe the first case of $B$ lineage $\mathrm{cHD}$ in which the $\mathrm{H} / \mathrm{RS}$ cells harbor virtually unmutated Ig V region genes.

\section{Results}

The H/RS cells in the CHD case presented here exhibit a typical immunophenotype, with co-expression of CD30 and CD15 (Fig. 1). The H/RS cells have phenotypic features of both the $B$ and the $T$ lineage in that they partly express the B-cell antigen CD20 and the cytotoxic T-cell markers, granzyme B and TIA-1. B and $T$ lineage markers are found only in a minority of $\mathrm{cHD}$ and have not been reported to be expressed by H/RS cells in the same case (Burke, 1992; Küppers and Rajewsky, 1998). The H/RS cells are Epstein-Barr virus (EBV)-positive as assessed by amplification of a specific fragment of the EBV-nuclear antigen-1 gene by single-cell PCR (Table 1) and by in situ hybridization for EBV-encoded small RNA. Because the majority of anaplastic large-cell lymphomas express one or
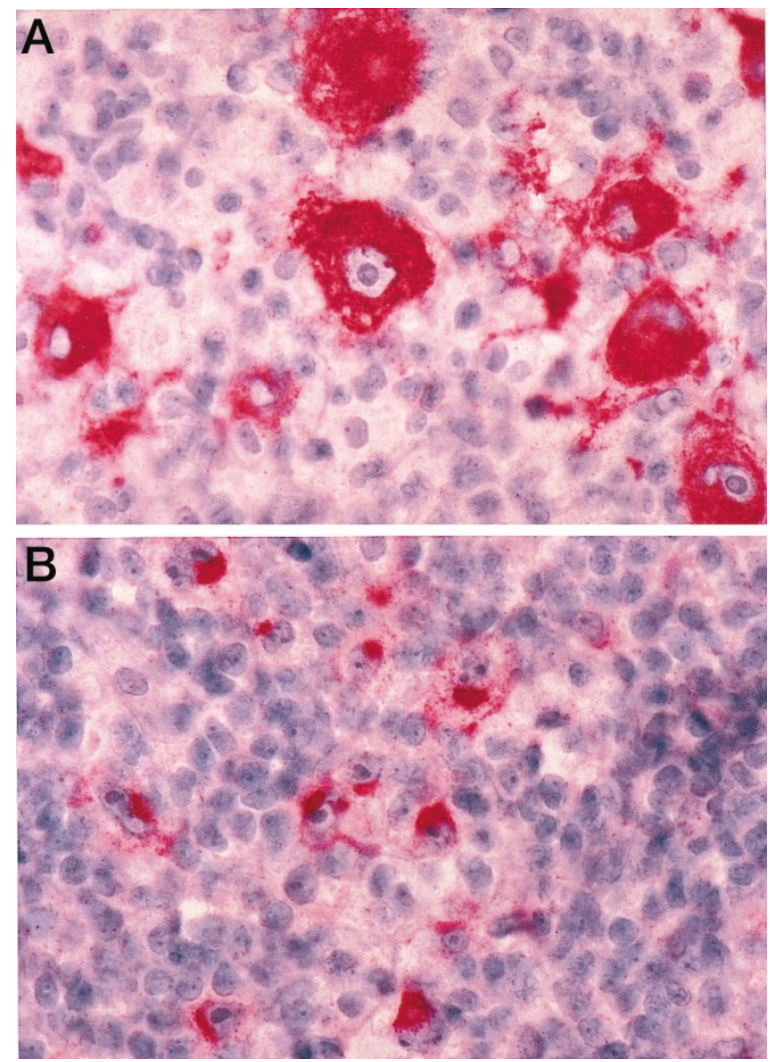

Figure 1.

Immunophenotype of Hodgkin- and Reed-Sternberg (H/RS) cells. CD30 immunoreactivity of paraffin-embedded sections from the case of $\mathrm{CHD}$ studied here (subtype mixed cellularity diagnosed on cervical lymph node biopsy at first presentation) ( $\mathrm{A}$, original magnification, $\times 80$ ). Hodgkin cells show membrane-bound and intracytoplasmic immunoreactivity for CD15 (B, original magnification, $\times 60$ ). more of the cytoxic T-cell markers studied here, diagnosis of cHD was further corroborated by demonstrating that the H/RS cells lack expression of the nucleophosmin-anaplastic lymphoma kinase molecule (Weiss et al, 1995). The nucleophosminanaplastic lymphoma kinase fusion protein arises from the translocation $\mathrm{t}(2 ; 5)$ ( $\mathrm{p} 23$; q35) which is typically seen in anaplastic large-cell lymphomas but not in cHD (Weiss et al, 1995).

A total of $120 \mathrm{H} / \mathrm{RS}$ cells were micromanipulated from sections stained for CD30 and granzyme B in three experiments $(39,51$, and $30 \mathrm{H} / \mathrm{RS}$ cells, respectively) and analyzed by single-cell PCR. The first experiment (39 H/RS cells) was omitted from analysis because there was an indication of PCR contamination (see "Materials and Methods"). Derivation from either the B or the $\mathrm{T}$ lineage is possible for $\mathrm{H} / \mathrm{RS}$ cells expressing cytotoxic T-cell markers (Müschen et al, 2000). Micromanipulated $\mathrm{H} / \mathrm{RS}$ cells were analyzed for Ig and TCR $\beta$ gene rearrangements (Table 1).

No TCR $\beta$ VDJ- or DJ-gene rearrangements were obtained from the analysis of $51 \mathrm{H} / \mathrm{RS}$ cells (Table 1), although fragments specific for germline configuration of the TCR $C \beta 1$ and $C \beta 2$ loci were repeatedly amplified (Table 1). However, three clonal Ig-gene rearrangements, namely a $V_{\mathrm{H}} 1-$, a $\mathrm{V}_{\kappa} 2$-, and a $\mathrm{V}_{\kappa} 3$-gene rearrangement, were amplified from $81 \mathrm{H} / \mathrm{RS}$ cells. Hence, this case represents another example of $\mathrm{cHD}$ in which the $H / R S$ cells expressed $T$ lineage markers although derived from a mature $\mathrm{B}$ cell (Müschen et al, 2000).

The $V_{H}$ 1-46 gene rearrangement was in-frame and potentially functional. The $\mathrm{V}_{\kappa} 2$ family pseudogene A18 was rearranged out-of-frame resulting in a nonfunctional rearrangement on one allele. However, the other allele carried a potentially functional rearrangement of the $V_{\kappa} 3$ family gene, L2. Thus, the configuration of the $\mathrm{lg} \mathrm{H}$ - and $\lg \kappa$-gene loci was compatible with expression of a functional BCR. $\lg \lambda$-gene rearrangements were not obtained.

Within $320 \mathrm{bp}$ of the $\mathrm{V}_{\mathrm{H}} \mathrm{D}_{\mathrm{H}} \mathrm{J}_{\mathrm{H}}$-gene sequence and 580 bp of the $V_{\kappa} J_{\kappa}$-gene sequence there was only one mismatch to the most homologous germline genes. This mismatch, at codon 11 of the $\mathrm{V}_{\mathrm{H}}$ 1-46 gene (resulting in a conservative val to leu replacement) (Table 2) might represent either a rare germline polymorphism or a single somatic mutation. To determine whether further differences from germline sequences were present within the rearranged $\mathrm{lgH}-$ and $\mathrm{Ig}_{\kappa}-$ genes, additional regions of the leader, leader intron, and framework region I of the $\mathrm{V}_{\mathrm{H}} 1-46, \mathrm{~V}_{\kappa} 2(\mathrm{~A} 18)$, and $V_{\kappa} 3$ (L2) genes were amplified and sequenced. Additionally, downstream $\mathrm{J}_{\mathrm{H}^{-}}$regions and downstream $\mathrm{J}_{\kappa}$-regions were analyzed because these regions are also possible targets for somatic hypermutation. However, all of these sequences were unmutated. In a total of 0.7 kilobases of $\mathrm{lgH}$ sequence there was only the single mismatch mentioned above. Within 1.5 kilobases of the rearranged $V_{\kappa} 2$ and $V_{\kappa} 3$ genes, including adjacent regions, there was no mismatch to the respective germline genes. 
Table 1. Summary of Single Cell PCR Analysis of Micromanipulated H/RS Cells

\begin{tabular}{|c|c|c|c|c|c|c|c|c|}
\hline \multirow[b]{2}{*}{ Experiment } & \multirow{2}{*}{\multicolumn{2}{|c|}{ Immunohistochemistry }} & \multirow[b]{2}{*}{ Gene locus $^{a}$} & \multicolumn{2}{|c|}{ PCR products } & \multicolumn{3}{|c|}{$\begin{array}{l}\text { Rearrangements/germline } \\
\text { configuration }^{c}\end{array}$} \\
\hline & & & & $\begin{array}{c}\mathrm{H} / \mathrm{RS} \\
\text { cells } \\
\text { positive }\end{array}$ & Total & Sequenced & Repeated & Unique \\
\hline \multirow[t]{16}{*}{ I } & CD30 & & $\lg \mathrm{H}$ & $9 / 41$ & $9 \mathrm{~V}_{\mathrm{H}} 1$ & 9 & $9 \mathrm{~V}_{\mathrm{H}} 1$ & \multirow{20}{*}{$1 \mathrm{~V}_{\mathrm{H}^{3}}$} \\
\hline & \multirow{2}{*}{\multicolumn{2}{|c|}{ Granzyme B }} & \multirow[t]{2}{*}{$\lg \mathrm{H}$} & $3 / 10$ & \multirow{2}{*}{$\begin{array}{l}2 V_{H} 1 \\
1 V_{H} 3\end{array}$} & 2 & $2 V_{H} 1$ & \\
\hline & & & & & & 1 & & \\
\hline & \multirow{4}{*}{\multicolumn{2}{|c|}{ CD30 }} & \multirow[t]{4}{*}{$\lg \kappa$} & $15 / 41$ & \multirow{2}{*}{$\begin{array}{l}13 V_{\kappa} 2 \\
10 V_{\kappa} 3\end{array}$} & 13 & $13 V_{\kappa} 2$ & \\
\hline & & & & & & 10 & 10 Vк3 & \\
\hline & & & & $10 / 10$ & $10 \mathrm{KDE}$ germline ${ }^{b}$ & 10 & $\begin{array}{l}10 \mathrm{KDE} \\
\text { germline }\end{array}$ & \\
\hline & & & & $9 / 10$ & $\begin{array}{l}9 \mathrm{~J}_{\kappa} \mathrm{C} \kappa \\
\text { intron-KDE }\end{array}$ & 4 & $\begin{array}{l}4 \mathrm{~J}_{\kappa} \mathrm{C} \kappa \\
\text { intron-KDE }\end{array}$ & \\
\hline & \multirow{3}{*}{\multicolumn{2}{|c|}{ Granzyme B }} & \multirow[t]{2}{*}{$\lg \kappa$} & $3 / 10$ & \multirow{2}{*}{$\begin{array}{l}3 V_{\kappa} 2 \\
2 V_{\kappa} 3\end{array}$} & 3 & \multirow{2}{*}{$3 V_{\kappa 2}$} & \\
\hline & & & & & & 2 & & \\
\hline & & & $\lg \lambda$ & $0 / 12$ & & & & \\
\hline & CD30 & & \multirow{2}{*}{$\begin{array}{l}\text { TCR C } \beta 1 \\
\text { TCR C } \beta 1\end{array}$} & $15 / 41$ & 15 germline & & 15 germline & \\
\hline & \multicolumn{2}{|l|}{ Granzyme B } & & $7 / 10$ & 7 germline & & 7 germline & \\
\hline & & & TCR C $\beta 2$ & $15 / 41$ & \multirow{2}{*}{15 germline } & & 15 germline & \\
\hline & \multirow{2}{*}{\multicolumn{2}{|c|}{$\begin{array}{l}\text { Granzyme B } \\
\text { CD30 }\end{array}$}} & TCR C $\beta 2$ & $6 / 10$ & & & 6 germline & \\
\hline & & & EBNA-1 & $21 / 41$ & 21 EBNA-1 & & & \\
\hline & Granzyme B & & EBNA-1 & $6 / 10$ & 6 EBNA-1 & & & \\
\hline II & CD30 & & $\lg \mathrm{H}$ & $7 / 30$ & $7 \mathrm{~V}_{\mathrm{H}} 1$ & & & \\
\hline & CD30 & & $\lg \kappa$ & $14 / 30$ & $\begin{array}{l}8 V_{\kappa} 2 \\
8 V_{\kappa} 3\end{array}$ & & & \\
\hline & & & & & 13 KDE germline & 13 & $\begin{array}{l}13 \mathrm{KDE} \\
\text { germline }\end{array}$ & \\
\hline & & & & $13 / 30$ & $\begin{array}{l}13 \mathrm{~J} \kappa \mathrm{C} \kappa \\
\text { intron-KDE }\end{array}$ & 6 & $\begin{array}{l}6 \mathrm{~J} \kappa \mathrm{C} \kappa \\
\text { intron-KDE }\end{array}$ & \\
\hline Cont & & & Micromanipu & & & orted by flov & cytometry & \\
\hline Gene I & cus & B cells & & er controls & & ells & To & \\
\hline $\lg \mathrm{H}$ & & $10 / 30$ & & & $3 / 4$ & & & \\
\hline $\lg \kappa$ & & $2 / 10$ & & & $2 / 4$ & & & \\
\hline $\lg \lambda$ & & & & & $1 / 3$ & & & \\
\hline TCR C $\beta$ & & & & 0 germline & $4 / 6 \mathrm{ger}$ & lline & $8 / 18$ & DJ \\
\hline EBNA-1 & & & 0 & & 2/2 (EB & ${ }^{+}$B cells) & & \\
\hline
\end{tabular}

H/RS, Hodgkin- and Reed-Sternberg; EBNA-1, Epstein-Barr virus nuclear antigen-1; KDE, Kappa deleting element.

${ }^{a}$ For IgH and IgL loci only V(D)J-rearrangements, for TCR $\beta$ loci VDJ- and DJ rearrangements as well as germline configuration were analyzed. IgH- and Ig $\kappa^{-}$gene rearrangements were amplified using framework region I- and leader-specific primers.

${ }^{b}$ Only $\mathrm{V}_{\kappa}{ }^{+}$cells were analyzed for KDE rearrangements.

${ }^{c}$ Germline configuration was identified by specific primer sets.

$V_{\kappa} J_{\kappa}$ joints can be transcriptionally silenced and exempted from somatic hypermutation by rearrangement of the kappa deleting element (KDE) to a recombination signal sequence in the $\mathrm{J}_{\kappa}-\mathrm{C}_{\kappa}$ intron (Klein et al, 1998; Siminovitch et al, 1985). To exclude the possibility that the lack of somatic mutations in the $V_{\kappa} J_{\kappa}$ joints was caused by KDE recombinations, the rearrangement status of the KDE in the H/RS cells was studied. A fragment indicative of the germline configuration of the $\mathrm{KDE}$ and a clonal $\mathrm{J}_{\kappa} \mathrm{C}_{\kappa}$ intron-KDE rearrangement were repeatedly amplified (Table 1). This indicated that one of the two $V_{\kappa} J_{\kappa}$ joints was inactivated by KDE rearrangement, whereas the $V_{\kappa} J_{\kappa}$ rearrangement on the other allele was not. Thus, one of the two $V_{\kappa}$-gene rearrangements could be transcribed and should have been accessible to somatic hypermutation.

Given that the $V_{H}$ and $V_{\kappa}$ region genes were virtually unmutated, the possibility arose that the H/RS cells might stem from a naive rather than an antigenexperienced B cell. Therefore, the H/RS cells were investigated by immunohistochemistry using antibodies to Bcl-6 and CD138, which are thought to be markers of GC or post-GC origin of $\mathrm{H} / \mathrm{RS}$ cells, respectively (Carbone et al, 1999). Approximately half of the H/RS cells were positive for Bcl-6 but not for CD138. 
Table 2. Sequence Analysis of Clonal Rearrangements Obtained from H/RS Cells ${ }^{a}$

\begin{tabular}{ccccccc}
\hline $\begin{array}{c}\text { Gene } \\
\text { locus }\end{array}$ & \multicolumn{1}{c}{$\begin{array}{c}\text { Rearrangement/ } \\
\text { germline }\end{array}$} & In-frame & $\begin{array}{c}\text { Potentially } \\
\text { functional }\end{array}$ & \% mutation & $\begin{array}{c}\text { Intraclonal } \\
\text { diversity }\end{array}$ & Remarks \\
\hline $\lg \mathrm{H}$ & $\mathrm{V}_{\mathrm{H}} 1-46-\mathrm{D} 3-22-\mathrm{J}_{\mathrm{H}} 4 \mathrm{~b}$ & $\mathrm{Yes}$ & $\mathrm{Yes}$ & 0.1 & No & 1 nucleotide difference \\
$\lg \kappa$ & $\mathrm{V}_{\kappa} 2(\mathrm{~A} 18)-\mathrm{J}_{\kappa} 5$ & $\mathrm{No}$ & $\mathrm{No}$ & 0 & No & Pseudogene; translational stop \\
& $\mathrm{V}_{\kappa} 3(\mathrm{~L} 2)-\mathrm{J}_{\kappa} 2$ & $\mathrm{Yes}$ & $\mathrm{Yes}$ & 0 & No & \\
& $\mathrm{J}_{\kappa} \mathrm{C} \kappa$ intron-KDE & $\mathrm{n} / \mathrm{a}$ & $\mathrm{n} / \mathrm{a}$ & 0 & No & Allele assignment unclear \\
$\operatorname{TCR} \beta$ & $\mathrm{C} \beta 1$ cluster germline & $\mathrm{n} / \mathrm{a}$ & $\mathrm{n} / \mathrm{a}$ & 0 & No & \\
& $\mathrm{C} \beta 2$ cluster germline & $\mathrm{n} / \mathrm{a}$ & $\mathrm{n} / \mathrm{a}$ & 0 & No & \\
\hline
\end{tabular}

H/RS, Hodgkin- and Reed-Sternberg; KDE, kappa deleting element; Ig, immunoglobulin; TCR $\beta$, T-cell receptor $\beta$.

${ }^{a}$ Sequence data from the four rearrangements are available at EMBL/GenBank under accession numbers 291990-291994.

\section{Discussion}

In all informative cases of B-cell lineage CHD (41 in total) analyzed so far (Bräuninger et al, 1999a; Irsch et al, 1998; Kanzler et al, 1996a, 1996b; Küppers et al, 1994; Marafioti et al, 1999, 2000; Müschen et al, 2000; Vockerodt et al, 1998), the H/RS cells harbor somatically mutated $\mathrm{lg}$ genes with mutation frequencies of the $\mathrm{V}_{\mathrm{H}}$ genes between $2 \%$ and $23 \%$ (average 10\%; Klein et al, 1998). In the H/RS cells analyzed here, only one difference from the most homologous germline gene was detected in the Ig heavy chain gene rearrangement and no mutation was detected within the two $\lg \kappa$ light chain gene rearrangements. This might be indicative of an origin of the H/RS-cell clone from a naive B cell. Besides naive B cells, many "founder" cells of GC also carry unmutated Ig $\mathrm{V}$ region genes (Lebecque et al, 1997; McHeyzer-Williams et al, 1993). Therefore, derivation of the $\mathrm{H} / \mathrm{RS}$ cells harboring unmutated $\mathrm{V}$ region genes from an early GC $\mathrm{B}$ cell is an alternative possibility. Moreover, the single nucleotide difference in the $V_{H}$ region gene may represent a first point mutation introduced by the somatic hypermutation machinery. A potential GC B cell derivation of the $H / R S$ cells in the present case is also supported by the expression of Bcl-6 in a fraction of the H/RS cells. Thus, the unprecedented lack of somatic mutation in the Ig $\mathrm{V}$ region genes in the present case remains an ambiguous finding and does not definitely indicate that a naive $\mathrm{B}$ cell was the precursor of the tumor clone. The finding that H/RS cells do not always harbor somatically mutated $\mathrm{V}$ region genes is reminiscent of chronic lymphocytic B-cell leukemia, which comprises two subsets that are thought to be derived from antigen-experienced and naive B cells, respectively (Damle et al, 1999; Hamblin et al, 1999). However, the cases of $\mathrm{CHD}$ in which the H/RS cells harbor unmutated $\mathrm{lg}$ genes are apparently very rare, as opposed to chronic lymphocytic B-cell leukemia.

BCR function was impaired because of obviously destructive Ig gene mutations (see "Introduction") in 12 of 41 cases of CHD, defining a pre-apoptotic GC B cell as the precursor of the tumor clone (Jox et al, 1999; Kanzler et al, 1996b; Küppers et al, 1994; Marafioti et al, 2000; Müschen et al, 2000). In the case of $\mathrm{cHD}$ presented here, the $\mathrm{lg} \mathrm{V}$ region genes analyzed were virtually unmutated. This suggests that, in this case, cHD developed in the absence of obviously destructive somatic mutations or other mutations reducing affinity to antigen.

Does this argue against an origin of the disease in this patient from a pre-apoptotic GC B cell? We do not believe that this is the case. $B$ cells seem to be programmed to undergo apoptosis in the absence of positive selection by antigen from the time of entry into the GC environment (Fig. 1), before the onset of somatic hypermutation (Lebecque et al, 1997). GC B cells are stringently selected for the acquisition of somatic mutations improving affinity for the immunizing antigen. Thus, it is expected that not only cells that have acquired mutations interfering with antigen binding, but also cells that carry neutral mutations or have not yet initiated hypermutation (ie, GC "founder" cells) and therefore fail to successfully compete for antigen with their companions, will be among those cells that undergo apoptosis in GC (Fig. 2). Thus, in accordance with the scenario of a derivation of $\mathrm{H} / \mathrm{RS}$ cells from pre-apoptotic GC B cells, one would predict that in rare cases of $\mathrm{CHD}, \mathrm{GC}$ "founder" B cells harboring as yet unmutated $V$ region genes should be the precursors of the tumor clone.

\section{Materials and Methods}

\section{Immunohistochemistry}

Tissue sections were taken from a cervical lymph node of a 68-year-old patient at first presentation. Immunohistochemistry was performed on $7-\mu \mathrm{m}$-thick frozen tissue sections, with antibodies against CD30 (Fig. 1A), CD20, anaplastic lymphoma kinase (ALK)-1 (Dako, Glostrup, Denmark), CD15 (Becton Dickinson, Mountain View, California; Fig. 1B), CD3 (Ortho Diagnostic Systems, Raritan, New Jersey), Bcl-6 (Novocastra, Newcastle-upon-Trent, United Kingdom), CD138 (syndecan-1; Serotec, Oxford, United Kingdom), T-cell receptor (TCR) $\alpha / \beta$ (T Cell Diagnostics, Woburn, Massachusetts), perforin (Neo Markers, Union City, California), granzyme B (Monosan, Am Uden, The Netherlands), or TIA-1 (Immunotech, Marseilles, France).

\section{Micromanipulation and Single-Cell PCR for Ig and TCR $\beta$ Genes}

Immunoreactive cells were mobilized and aspirated with a micropipette fixed to a hydraulic micromanipu- 


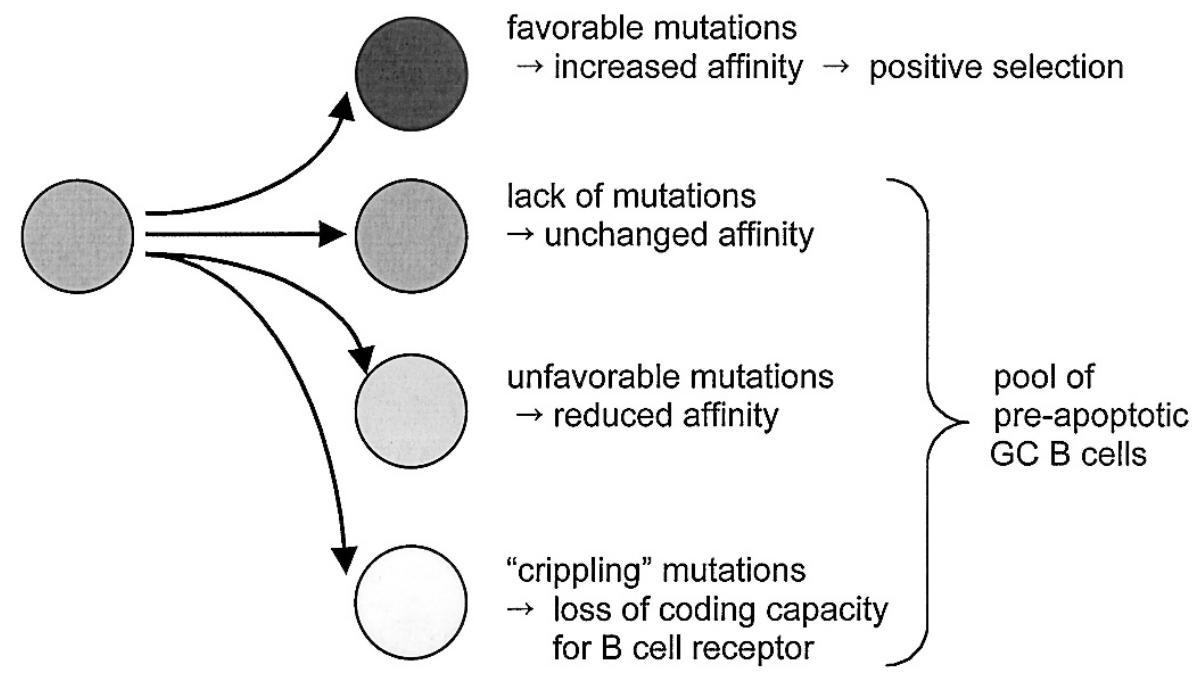

Figure 2.

Derivation of the H/RS cell clone from a pre-apoptotic germinal center (GC) B cell. GC B cells are committed to die by apoptosis unless they are positively selected for a B-cell receptor of high affinity to antigen. The failure to increase affinity to antigen during the GC reaction may have several reasons, one of which is the lack of somatic mutations within the $\lg \mathrm{V}$ region genes as discussed here.

lator (Küppers et al, 1993). Buffer covering the sections was aspirated for negative controls for the PCR analysis. For positive controls for PCR, single B and T cells were either micromanipulated or sorted by flow cytometry.

To analyze individual micromanipulated cells for $\lg \mathrm{H}, \lg \kappa, \lg \lambda$, and TCR $\beta$ VDJ- and DJ-gene rearrangements or TCR $\beta$ germline configuration, whole genome pre-amplification (Zhang et al, 1992) was performed with slight modifications. Aliquots of $4 \mu \mathrm{l}$ from these reactions were then subjected to two rounds of seminested PCR amplification as previously described. Briefly, rearranged $\mathrm{V}_{\mathrm{H}^{-}}, \mathrm{V}_{\kappa^{-}}$, and $\mathrm{V} \lambda$ - genes were amplified using family-specific framework region I (FRI) $\mathrm{V}$-gene primers and two sets of $\mathrm{J}_{\mathrm{H}^{-}}, \mathrm{J}_{\kappa^{-}}$, and $\mathrm{J} \lambda$-primers in a semi-nested approach (Bräuninger et al, 1999b; Kanzler et al, 1996a). In some experiments, IgH- and Ig $\kappa_{\text {-gene }}$ rearrangements were amplified using $\mathrm{V}_{\mathrm{H}}$ leader- (Bräuninger et al, 1997) and $V_{\kappa}$ leader-specific primers instead of $\mathrm{V}_{\mathrm{H}^{-}}$and $\mathrm{V}_{\kappa}$-FRI-primers. The following $V_{\kappa}$ leader family-specific primers were used: 5'-GCTCAGCTCCTGGGGCTCCTGC-3' for $\mathrm{V}_{\kappa} 1 \mathrm{~L}, 5^{\prime}-$ CTCAGCTYCTGGGGCTGCTAATGCT-3' for $\mathrm{V}_{\kappa} 2 \mathrm{~L}, 5^{\prime}$ CTCAGTTAGGACCCAGABGGAACCAT-3' for $\mathrm{V}_{\kappa} 3 \mathrm{~L}$, and 5'-GGGGCAGCAAGATGGTGTTGCAGA-3' for $\mathrm{V}_{\kappa} 4 \mathrm{~L}$. Within the $\mathrm{IgH}$ locus, the intronic sequence flanked by the $\mathrm{J}_{\mathrm{H}^{4}}$ - and the $\mathrm{J}_{\mathrm{H}}$ 5-gene was amplified using 5' -TCCTCAGGTGAGTCCTCAACCTCT-3' and 5' CTCACAАССТСТСТССТGСТТА- $3^{\prime}$ as external and internal forward primers, respectively, and 5'-TAGGCCTCTGGGGTCCAATGC-3' as reverse primers. The intron between the $\mathrm{V}_{\kappa} \mathrm{J}_{\kappa}$-joint and the next downstream $J_{\kappa}$-genes were amplified using primers specific for the rearranged $\mathrm{V}_{\kappa}$-genes and primers for the next downstream $\mathrm{J}_{\kappa}$-genes. Rearrangements of the KDE to a $V_{\kappa}$-germline gene segment or a recombination signal sequence site in the $J_{\kappa} \mathrm{C}_{\kappa}$ intron, or to a specific fragment for germline configuration of this element, were amplified as previously described (Küppers et al, 1996).
The same cells were subjected to semi-nested amplification of TCR $\beta$ VDJ and DJ rearrangements and fragments specific for germline configuration of the $\mathrm{C} \beta 1$ and $\mathrm{C} \beta 2$ loci, as previously described (Müschen et al, 2000; Roers et al, 1998).

PCR products were gel-purified and directly sequenced using the BigDye Terminator cycle sequencing kit and an automated sequencer (ABI 377; Applied Biosystems, Weiterstadt, Germany). Sequences were compared with the EMBL IMGT database (http://www.genetik.uni-koeln.de/dnaplot/).

In a first experiment, one clonal $\mathrm{V}_{\mathrm{H}}$ and two clonal $V_{\kappa}$ gene rearrangements were repeatedly amplified from 39 micromanipulated H/RS cells. These rearrangements were also obtained when DNA isolated from whole tissue sections of the biopsy specimen was analyzed for $\mathrm{V}_{\mathrm{H}}$ and $\mathrm{V}_{\kappa}$ gene rearrangements in one round of PCR with 35 cycles (data not shown). Because an additional $\mathrm{V}_{\mathrm{H}} 3$ gene rearrangement (outof-frame and unmutated) was amplified in this PCR, the whole genome preamplification aliquots of the 39 $\mathrm{H} / \mathrm{RS}$ cells were analyzed again for $\mathrm{V}_{\mathrm{H}^{3}}$ gene rearrangements by single-cell PCR. Whereas the first three attempts did not give rise to a single $V_{H^{3}}$ amplificate, eight polyclonal $\mathrm{V}_{\mathrm{H}} 3$ gene rearrangements (all unrelated to the $\mathrm{V}_{\mathrm{H}} 3$ gene amplified from the whole-tissue DNA) were obtained in the fourth amplification. These amplificates probably represent a PCR contamination of the whole-genome preamplification reactions in the fourth amplification. For this reason, the first micromanipulation and PCR experiment was completely omitted from analysis.

\section{Determination of Epstein-Barr Virus Infection}

Epstein-Barr virus (EBV)-infection of $\mathrm{H} / \mathrm{RS}$ cells was examined by in-situ hybridization for noncoding EBVencoded small RNA and by amplification of a fragment of the EBV-nuclear antigen-1 gene from single micro- 
manipulated $\mathrm{H} / \mathrm{RS}$ cells using the previously published primers in a semi-nested PCR (Müschen et al, 2000).

\section{Acknowledgements}

We are indebted to Julia Jesdinsky, Tanja Schaffer, and Christiane Gerhard for excellent technical assistance.

\section{References}

Bräuninger A, Hansmann ML, Strickler JG, Dummer R, Burg G, Rajewsky K, and Küppers R (1999a). Identification of common germinal-center B-cell precursors in two patients with both Hodgkin's disease and Non-Hodgkin's lymphoma. N Engl J Med 340:1239-1247.

Bräuninger A, Küppers R, Spieker T, Siebert R, Strickler JG, Schlegelberger B, Rajewsky K, and Hansmann ML (1999b). Molecular analysis of single $B$ cells from $T$ cell rich $B$ cell lymphoma reveals the derivation of the tumor cells from mutating GC B cells and exemplifies means by which immunoglobulin genes are modified in the GC B cells. Blood 93:2679-2687.

Bräuninger A, Küppers R, Strickler JG, Wacker HW, Rajewsky K, and Hansmann ML (1997). Hodgkin and ReedSternberg cells in lymphocyte predominant Hodgkin disease represent clonal populations of GC-derived tumor B cells [published correction appears in Proc Natl Acad Sci USA 94:14211]. Proc Natl Acad Sci USA 94:9337-9342.

Burke JS. (1992) Hodgkin's disease: Histopathology and differential diagnosis. In: Knowles DM, editor. Neoplastic hematopathology. Baltimore: Williams and Wilkins, 497-533.

Carbone A, Gloghini A, and Gaidano G (1999). Expression of BCL-6 protein and CD138/syndecan-1 as B-cell markers in Hodgkin's disease. Int J Biol Markers 14:144-148.

Damle RN, Wasil T, Fais F, Ghiotto F, Valetto A, Allen SL, Buchbinder A, Budman D, Dittmar K, Kolitz J, Lichtman SM, Schulman $P$, Vinciguerra VP, Rai KR, Ferrarini M, and Chiorazzi N (1999). Ig V gene mutation status and CD38 expression as novel prognostic indicators in chronic lymphocytic leukemia. Blood 94:1840-1847.

Goossens T, Klein U, and Küppers R (1998). Frequent occurrence of deletions and duplications during somatic hypermutation: Implications for oncogene translocations and heavy chain disease. Proc Natl Acad Sci USA 95:2463-2468.

Hamblin TJ, Davis Z, Gardiner A, Oscier DG, and Stevenson FK (1999). Unmutated Ig $\mathrm{V}(\mathrm{H})$ genes are associated with a more aggressive form of chronic lymphocytic leukemia. Blood 94:1848-1854.

Irsch J, Nitsch S, Hansmann ML, Rajewsky K, Tesch H, Diehl V, Jox A, Küppers R, and Radbruch A (1998). Isolation of viable Hodgkin and Reed-Sternberg cells from Hodgkin disease tissues. Proc Natl Acad Sci USA 95:10117-10122.

Jox A, Zander T, Küppers R, Irsch J, Kanzler H, Kornacker M, Bohlen H, Diehl V, and Wolf J (1999). Somatic mutations within the untranslated regions of rearranged lg-genes in a case of classical Hodgkin's disease as a potential cause for the absence of $\mathrm{Ig}$ in the lymphoma cells. Blood 93:39643972.

Kanzler H, Hansmann ML, Kapp U, Wolf J, Diehl V, Rajewsky K, and Küppers R (1996a). Molecular single cell analysis demonstrates the derivation of a peripheral blood-derived cell line (L1236) from the Hodgkin/Reed-Sternberg cells of a Hodgkin's lymphoma patient. Blood 87:3429-3436.

Kanzler H, Küppers R, Hansmann ML, and Rajewsky K (1996b). Hodgkin and Reed-Sternberg cells in Hodgkin's disease represent the outgrowth of a dominant tumor clone derived from (crippled) germinal center B cells. J Exp Med 184:495-505.

Klein U, Goossens T, Fischer M, Kanzler H, Bräuninger A, Rajewsky K, and Küppers R (1998). Somatic hypermutation in normal and transformed human B cells. Immunol Rev 162:261-280.

Küppers R, Hajadi M, Plank L, Rajewsky K, and Hansmann $M L$ (1996). Molecular Ig gene analysis reveals that monocytoid B cell lymphoma is a malignancy of mature B cells carrying somatically mutated $\mathrm{V}$ region genes and suggests that rearrangement of the kappa-deleting element (resulting in deletion of the Ig kappa enhancers) abolishes somatic hypermutation in the human. Eur $\mathrm{J}$ Immunol 26:1794-1800.

Küppers R and Rajewsky K (1998). The origin of Hodgkin and Reed-Sternberg cells in Hodgkin's disease. Annu Rev Immunol 6:471-493.

Küppers R, Rajewsky K, and Hansmann ML (1997). Diffuse large cell lymphomas are derived from mature B cells carrying $\mathrm{V}$ region genes with a high load of somatic mutation and evidence of selection for antibody expression. Eur J Immunol 27:1398-1405.

Küppers R, Rajewsky K, Zhao M, Simons R, Laumann R, Fischer R, and Hansmann ML (1994). Hodgkin disease: Hodgkin and Reed-Sternberg cells picked from histological sections show immunoglobulin gene rearrangements and appear to be derived from B cells at various stages of development. Proc Natl Acad Sci USA 91:10962-10966.

Küppers R, Zhao M, Hansmann ML, and Rajewsky K (1993). Tracing $B$ cell development in human germinal centres by molecular analysis of single cells picked from histological sections. EMBO J 12:4955-4967.

Lebecque S, de Bouteiller O, Arpin C, Banchereau J, and Liu YJ (1997). Germinal center founder cells display propensity to apoptosis before onset of somatic mutation. J Exp Med 185:563-571.

Liu YJ, de Bouteiller O, and Fugier-Vivier I (1997). Mechanisms of selection and differentiation in germinal centers. Curr Opin Immunol 9:256-262.

Liu YJ, Joshua DE, Williams GT, Smith CA, Gordon J, and MacLennan ICM (1989). Mechanism of antigen-driven selection in germinal centres. Nature 342:929-931.

Marafioti T, Hummel M, Anagnostopoulos I, Foss HD, Huhn $D$, and Stein H (1999). Classical Hodgkin's disease and follicular lymphoma originating from the same GC B cell. J Clin Oncol 17:3804-3809.

Marafioti T, Hummel M, Foss HD, Laumen H, Korbjuhn P, Anagnostopoulos I, Lammert H, Demel G, Theil J, Wirth T, and Stein H (2000). Hodgkin and Reed-Sternberg cells represent an expansion of a single clone originating from a germinal center B-cell with functional immunoglobulin gene rearrangements but defective immunoglobulin transcription. Blood 95:1443-1450.

McHeyzer-Williams MG, McLean MJ, Lalor PA, and Nossal GJV (1993). Antigen-driven B cell differentiation in vivo. J Exp Med 178:295-307. 
Müschen M, Rajewsky K, Bräuninger A, Baur AS, Oudejans JJ, Roers A, Hansmann ML, and Küppers R (2000). Rare occurrence of classical Hodgkin's disease as a T cell lymphoma. J Exp Med 191:387-394.

Ohno T, Trenn G, Wu G, Abou-Elella A, Reis HE, and Chan WC (1998). The clonal relationship between nodular sclerosis Hodgkin's disease with a clonal Reed-Sternberg cell population and a subsequent B-cell small noncleaved cell lymphoma. Mod Pathol 11:485-490.

Rajewsky K (1996). Clonal selection and learning in the antibody system. Nature 381:751-758.

Roers A, Montesinos-Rongen M, Hansmann ML, Rajewsky K, and Küppers R (1998). Amplification of TCR $\beta$ gene rearrangements from micromanipulated single cells: T cells rosetting around Hodgkin and Reed-Sternberg cells in Hodgkin's disease are polyclonal. Eur J Immunol 28:24242431.
Siminovitch KA, Bakhshi A, Goldman P, and Korsmeyer SJ (1985). A uniform deleting element mediates the loss of kappa genes in human B cells. Nature 316:260-262.

Vockerodt $M$, Soares $M$, Kanzler $H$, Küppers $R$, Kube $D$, Hansmann ML, Diehl V, and Tesch H (1998). Detection of clonal Hodgkin and Reed-Sternberg cells with identical somatically mutated and rearranged $\mathrm{V}_{\mathrm{H}}$ genes in different biopsies in relapsed Hodgkin's disease. Blood 92:28992907.

Weiss LM, Lopategui JR, Sun JH, Kamel OW, Koo CH, and Glackin C (1995). Absence of the t $(2 ; 5)$ in Hodgkin's disease. Blood 85:2845-2847.

Zhang L, Cui X, Schmitt K, Hubert R, Navidi W, and Arnheim N (1992). Whole genome amplification from a single cell: Implication for genetic analysis. Proc Natl Acad Sci USA 89:5847-5851. 